\title{
THE PROBATE HOMESTEAD IN CALIFORNIA
}

The probate homestead in California was designed by the legislature "... to provide a place for the family and its surviving members where they may dwell in peace and serenity, conscious that it cannot be taken from them 'either by reason of their own necessity or improvidence or from the importunity of their creditors." " Property is set apart out of the decedent's estate to the surviving spouse ${ }^{2}$ and minor children ${ }^{3}$ free from hability for the debts of the estate. It is thereafter fully exempt from execution and sale in order to satisfy the claims of most of the creditors of the homestead owner as well.

The probate homestead should not be confused with the marital homestead which is declared by the husband and wife, or either of them, during coverture ${ }^{4}$ and which, with two exceptions, vests, on the death of either spouse, absolutely in the survivor. ${ }^{5}$ The differences between these two types of homesteads present the homeowner with the dilemma of having to weigh the advantages of homestead protection during his lifetime against the more liberal characteristics of the probate homestead which would be assigned to his widow if he should die without having declared a marital homestead. ${ }^{\circ}$

This Comment will review the law of probate homesteads as it exists in California today. It will also analyze the differences between

${ }^{1}$ Estate of Claussenius, 96 Cal. App. 2d 600, 612, 216 P.2d 485, 494 (1950).

2 Although the provisions apply equally to either the surviving husband or wife, the term "widow" will be used throughout this Comment to indicate the surviving spouse.

${ }^{3}$ For selection and designation of a homestead, see CAL. PROB. CODE $\$ 661$.

4 For a discussion of the marital homestead see Comment, 26 CALIF. L. REv. 241, 466 (1938).

5 Caz. Prob. Code $\S 663$. The marital homestead does not vest in the survivor if it was selected from the separate property of the decedent without his consent or if the surviving spouse has conveyed the homestead to the other spouse without expressly reserving her homestead rights.

Probate Code $\$ 663$ was amended in 1961 to provide that a marital homestead which is selected from the quasi-community property vests in the survivor in the same manner as a marital homestead selected fronl community property. If the statute is interpreted so as not to give effect to the quasi-community character of the property until after the death of the acquiring spouse, his vested rights have not been impaired. $C f$. Addison v, Addison, 62 A.C. 584, - P.2d -, 43 Cal. Rptr. 97 (1965); Estate of Miller, 31 Cal. 2d 191, 187 P.2d 722 (1947); Estate of Thornton, 1 Cal. 2d 1, 5, 33 P.2d 1, 3 (1934) (Langdon, J., dissenting).

${ }^{6}$ The probate homestead must be assigned to the widow regardless of its value. Estate of Nelson, 224 Cal. App. 2d 138, 36 Cal. Rptr. 352 (1964). It is thereafter wholly exempt from the claims of most subsequent creditors. See text accompanying notes 96-103 infra. The marital homestead, on the other hand, may be sold if it exceeds the statutory exemption limit and an amount equal to that limit set apart to the survivor. CAL. Prob. Code \$\$ 664-66. After the marital homestead has vested in the survivor, subsequent creditors may still reach any excess over the exemption limit. CAI. Crv. CODE $\$ \S 1245-59$. 
the probate homestead and the marital homestead which has devolved upon the surviving spouse, with a view toward creating a unified system of homestead legislation.

CONDITIONS UNDER WHICH THE PROBATE HOMESTEAD

MUST BE SET APART

The probate homestead in California is governed by section 661 of the Probate Code $^{7}$ which provides that, if no marital homestead has been selected or if the marital homestead was selected by the survivor out of the separate property of the decedent without his consent, the court nust set apart a probate homestead for the use of the surviving spouse and minor children. When either of these conditions exists, it is mandatory that the court set the property aside, ${ }^{8}$ even if the estate is insolvent. ${ }^{0}$ The probate court can exercise its discretion only upon the questions of the selection of the precise property to be awarded and, when separate property of the decedent is selected, the duration of the assignment. Although the demands of the family are paramount, when selecting property the court should also consider the rights of creditors and the financial status of the estate. ${ }^{10}$

Because of the compulsory nature of the statute, the court cannot, in the exercise of its discretion, refuse to set aside a probate homestead on the grounds that the widow already has a place in which to he. An extreme case is Estate of Firth ${ }^{11}$ in which the husband devised the family residence to his wife and another piece of residential property to his

7 "If no homestead has been selected, designated and recorded, or in case the homestead was selected by the survivor out of the separate property of the decedent, the decedent not having joined therein, the court, must select, designate and set apart and cause to be recorded a homestead for the use of the surviving spouse and the minor children, or, if there be no surviving spouse, then for the use of the minor child or children, out of the community property or quasi-community property or out of real property owned in common by the decedent and the person or persons entitled to have the homestead set apart, or if there be no commumity property or quasi-community property and no such property owned in common, then out of the separate property of the decedent. If the property set apart is the separate property of the decedent, the court can set it apart only for a limited period, to be designated in the order, and in no case beyond the lifetime of the surviving spouse, or, as to a child, beyond its minority; and, subject to such homestead right, the property remains subject to administration.

For the purposes of this section, the terms 'quasi-community property' and 'separate property' have the mcanings given those terms in Section 1237.5 of the Civil Code."

8 Estate of Firth, 145 Cal. 236, 78 Pac. 643 (1904).

9 Estate of Adams, 128 Cal. 380, 57 Pac. 569 (1900).

10 Estate of Nelson, 224 Cal. App. 2d 138, 36 Cal. Rptr. 352 (1964); Estate of Raymond, 137 Cal. App. 2d 134, 289 P.2d 890 (1955); Estate of Claussenius, 96 Cal. App. 2d 600, 216 P.2d 485 (1950); Estate of Hessler, 2 Coffey's Pro. Dec. 354 (1895).

11145 Cal. 236, 78 Pac. 643 (1904). 
adult children of a former marriage. On petition by the widow, the probate court set aside a homestead for her lifetime in the latter property. The children contended on appeal that the court's order was an abuse of discretion. The supreme court affirmed the order on the ground that the right to a probate homestead is independent of any other right or property that the widow may have. ${ }^{12}$

Thus it is clear that the decedent's testamentary power is subordinate to the authority of the probate court to appropriate the property for the use of the widow as a probate homestead. ${ }^{13}$ However, if the testator's intent is clearly expressed in the will, the widow may be put to an election to assert her statutory rights or stand upon her inheritance. ${ }^{14}$ As long as the testator can put his widow to an election by more careful drafting of the will, an occasional result such as that in Estate of Firth ${ }^{15}$ is not too objectionable. A inore difficult problein arises when the widow who owns substantial separate property petitions for a probate homestead in property which either is needed in order to satisfy the claims of creditors of the estate or has been devised to another. The testator cannot deprive the widow of her statutory right in this situation since there is no means of putting her to an election.

The current rule can be justified only on the basis of simplicity; it is not wholly responsive to the need to balance the interests of all of the persons who have a claim in the decedent's estate. In order to prevent a widow from successfully petitioning for a probate homestead solely for the purpose of keeping the property away from another, the probate court should be given some discretion to deny her petition where the circumstances would render sucli action more equitable. The scope of this discretion should be limited to cases in which the widow already has a place in which to live or could provide one for lierself without having to substantially impair her separate estate. If a probate lomestead is demed, the widow could still obtain protection from her subsequent creditors by declaring a homestead under the appropriate section of the Civil Code. ${ }^{18}$

12 The supreme court also indicated that a rule which makes the power of the probate court to set aside a probate homestead discretionary rather than mandatory must come from the legislature. See Estate of Firth, supra note 11. Since that time the legislature has re-codified the statutes dealing with probate inatters into a probate code and has amended the basic statutes several times without changing the compulsory language by which the court felt bound.

13 Sulzberger v. Sulzberger, 50 Cal. 385 (1875).

14 Estate of Ettlinger, 56 Cal. App. 2d 603, 132 P.2d 895 (1943).

15145 Cal. 236, 78 Pac. 643 (1904).

16 Civil Code \& 1260 provides that homesteads may be selected and claimed by any head of a family with an exemption limit of $\$ 15,000$, or by any other person with an exemption limit of $\$ 7,500$. If the widow does not qualify as a head of family as defined 


\section{II \\ PROPERTY SUBJECT TO THE PROBATE HOMESTEAD}

Probate Code section 661 neither defines homestead property nor imposes a limitation upon the value of property whicl can be set aside as a probate homestead. The general rule whicli lias been adopted by the courts is that property cannot be set aside to the widow unless the decedent could have declared it as a marital lomestead prior to his death. ${ }^{17}$ Civil Code section 1237 -wlich defines the marital homestead as the dwelling house together with outbuildings and the land on which the same are situated-and the cases decided thereunder can be used as guidelines for a definition of suitable probate homestead property.

The courts have not been strict in limiting the character of property which may be set aside. It is not necessary that the entire building be used as the family residence; the homestead character is not destroyed if a portion of the property is used for business purposes, ${ }^{18}$ or if the building is divided into flats ${ }^{10}$ or apartments..$^{20} \mathrm{~A}$ recent case allowed the widow a probate homestead in a thirty unit apartment building worth almost a quarter of a million dollars when she lived in one unit. ${ }^{21}$

Where the estate does not contain any suitable homestead property, the courts have refused to set aside a sum of money in lieu of such property. In Estate of $N o a h^{22}$ the only real property in the estate was a four story building, the separate property of the decedent, which was used solely for business purposes. The widow urged that the property be sold and that an amount equal to the marital lomestead exemption be paid to her in heu of a probate homestead. The court denied her request on the grounds that no provision of the statutes authorized such an order and that by strong implication such an order was prohibited. The court reasoned that the legislature, by providing for sale of the marital homestead where it exceeded the exemption himit and distribu-

by Civil Code $\$ 1261$, where she has been denied a probate homestead she should nevertheless be entitled to the $\$ 15,000$ exenuption. Cf. text accompanying note 137 infra.

17 See Estate of Carriger, 107 Cal. 618, 40 Pac. 1032 (1895); Kingsley v. Kingsley, 39 Cal. 665 (1870). The court created an exception to this rule in Estate of Henningsen, 199 Cal. 103, 247 Pac. 1082 (1926), when it held that if the property is otherwise suitable, a residence on it is not a prerequisite to assignment.

18 See, e.g., Estate of Ogburn, $105 \mathrm{Cal}$. 95, 38 Pac. 493 (1894) (tin shop); Coca Cola Bottling Co. v. Feliciano, 45 Cal. App. 2d 680, 114 P.2d 604 (1941) (hiquor store, warehouse, and gasoline pump).

19 See Estate of Levy, 141 Cal. 646, 75 Pac. 301 (1904).

${ }^{20}$ See Estate of Nelson, 224 Cal. App. 2d 133, 36 Cal. Rptr. 352 (1964).

21 Ibid.

2273 Cal. 590, 15 Pac. 290 (1887). 
tion of an amount equal to the statutory exemption to the survivor, ${ }^{23}$ impliedly prohibited the adoption of an analogous procedure with respect to other property in the estate. As an additional ground of decision the court said that since in this case the money sought would be the separate property of the decedent, the cash value of its use as a probate homestead could not be estimated.

Since the purpose of the probate homestead is to provide the widow with a place in which to hive, a rule which does not allow the court to award a sum of money in heu of property can perhaps be justified as consistent with a narrow interpretation of this purpose. However, if the widow would, in fact, buy a home with the money assigned to her, the court should alter its views on setting aside money in order to give the apartment dwelling widow the same measure of protection against creditors given to the widow whose husband was a homeowner. The following procedure would be consistent with the purpose of probate homestead legislation.

Since the probate homestead and the marital homestead which has devolved upon the surviving spouse serve the same purpose-providing a secure home for the surviving family of a decedent-the award ought to be limited to the amount of the exemption limit of the marital homestead. ${ }^{24}$ If the estate consists of community property the money could be given to the widow outright, on condition that she buy a home with it. If the estate was the separate property of the decedent, the procedure would be more complex, but still feasible. The court could order the personal representative to purchase a home selected by the widow to be used as a probate homestead. At the expiration of the limited period of assignment the court could either put the home into the decedent's estate and subject it to administration or order a sale of the home with the proceeds to go back into the decedent's estate. ${ }^{25}$

A problem similar to the above was raised in Estate of Galligher ${ }^{26}$ where the widow petitioned for a probate honestead in farmland. The court denied her request in spite of her offer to prove that she would move on to the land and erect a suitable home if the property were assigned to her. This decision will pose a problem to a widow in the event the family home is destroyed by fire or other catastrophe and her husband is either a victim of the event or dies before rebuilding can be conipleted. In

${ }^{23}$ CAC. PrOB. Code $\$ \$ 664-66$. The former version of these sections, Code of Civil Procedure $\$ 1476$, enacted in 1872 , was used as the basis for this decision.

24 CaI. Civ. Code $\$ 1260$. The $\$ 15,000$ exemption limit should apply whether or not the widow qualifies as a head of family. $C f$. text accompanying note 137 infra.

25 Probate Code $\S 661$ provides that when a probate homestead is set apart for a limited period of time the designated parcel remains subject to administration.

26134 Cal. 96, 66 Pac. 70 (1901). 
such a case, in order to protect the widow, the court should reverse its earlier holding and set aside the property on condition that she build a home thereon.

In addition to the nature of the property to be set aside, the court inust also consider the adequacy of the decedent's property interest in the land. The statute explicitly allows a probate homestead to be set aside out of community property, quasi-community property, ${ }^{27}$ property owned by the decedent and the homestead claimant as tenants in common, and the separate property of the decedent. Although there is no authority on this point, it is likely that property could not be set aside as a probate homestead if it was owned by the decedent in joint tenancy either with his widow or a third person. Property which is owned in joint tenancy passes to the survivor under the original instrument; it is not part of the decedent's estate. ${ }^{28}$ Therefore the court probably has no jurisdiction to set it aside as a probate homestead.

If the joint tenancy was between the spouses, the survivorship feature would prevent the decedent fron successfully devising the property to another. The property would go to the survivor free from the claims of creditors of the estate. ${ }^{29}$ If the widow desired protection from her creditors she could declare a homestead on the property. ${ }^{30}$

In Estate of Kachigian ${ }^{31}$ the supreme court affirmed the award of a probate homestead on land which the decedent and his brother owned as tenants in common. This was an easy case because there were two houses on the land, one of which had been the residence of decedent and his wife. If there had been only one house on the property the court would have been faced with a more difficult choice. In such a case a

27 Prior to 1957, property which is now denominated quasi-comnunity property as defined in Civil Code $\S 1237.5$, was treated as separate property for the purpose of setting apart a probate homestead. Estate of Niccolls, 164 Cal. 368, 129 Pac. 278 (1912). In 1957, Probate Code $\S 661$ was amended to provide that a probate homestead selected from quasi-community property is to be treated in the same numier as a probate homestead selected from conmumity property. Since quasi-community property which is set apart as a probate homestead does not vest in the survivor until after the death of the spouse who originally acquired the property, the statute, as amended, does not unconstitutionally deprive the decedent of a vested property right. Cf. Addison v. Addison, 62 A.C. 584, - P.2d -, 43 Cal. Rptr. 97 (1965); Estate of Miller, 31 Cal. 2d 191, 187 P.2d 722 (1947) ; Estate of Thornton, 1 Cal. 2d 1, 5, 33 P.2d 1, 3 (1934) (Langdon, J., dissenting). The term "community property," as hereinafter used in discussing the characteristics of a probate homestead, includes the term quasi-conmunity property.

28 E.g., Green v. Skinner, 185 Cal. 435, 197 Pac. 60 (1921); Estate of Harris, 169 Cal. 725, 147 Pac. 967 (1915).

${ }^{29}$ See, e.g., Hamel v. Gootkin, 202 Cal. App. 2d 27, 20 Cal. Rptr. 372 (1962); People v. Nogarr, 164 Cal. App. 2d 591, 330 P.2d 858 (1958); King v. King, 107 Cal. App. 2d 257, 236 P.2d 912 (1951).

30 For an analogous situation, see text accompanying note 16 supra.

3120 Cal. 2d 787, 128 P.2d 865 (1942). 
partition of the property might be the best solution. If the decedent had been living on the property, after partition the parcel with the hoine could be set aside to the widow. If the home were occupied by the cotenant of the decedent, the court could set aside the unimproved parcel to the widow on condition that she build a home thereon. If the property were not suitable for partition the court could order a sale of the property on condition that the widow invest her share of the proceeds in a home. However, in order to protect the widow in this fashion the court would have to alter its views on setting aside land or money in heu of a homestead. ${ }^{32}$

Although the statute provides that commumity property or property held by the spouses as tenants in common must be resorted to before the separate property of the decedent, the court has held that this requirement applies only when there are two or more equally suitable properties in the estate. In Estate of Raymond, ${ }^{33}$ the court awarded the widow the family home of seventeen and one-half years, the separate property of the decedent, instead of a bungalow which husband and wife had owned in common.

\section{III}

\section{DURATION AND TERMINATION OF THE PROBATE HOMESTEAD}

Since a probate homestead set apart out of community property cannot be limited in duration, ${ }^{34}$ the widow and minor children take title to the property in fee simple. The lomestead riglit continues in favor of the widow as long as she asserts it. ${ }^{35}$ This effectively means that the property is impressed with homestead characteristics until she either sells the property or dies ${ }^{\mathbf{3 6}}$ since there is no statutory means of abandoning a probate homestead. The estate is unconditional and is not forfeited because of failure to reside continuously thereon or by holding possession through tenants. ${ }^{37}$ The homestead characteristics terminate as to the children when they reach majority. In defining the nature of the rights of the children who have attained majority after having been assigned a probate homestead out of community property the supreme court has said, "When the children arrive at majority, their interest in the homestead, as a homestead, ceases, for they no longer constitute a part of the family, and whatever property rights

32 See text accompanying notes 22-26 supra.

33137 Cal. App. 2d 134, 289 P.2d 890 (1955).

34 See, e.g., Estate of Rogoff, 205 Cal. App. 2d 650, 23 Cal. Rptr. 334 (1962); Estate of Davis, 86 Cal. App. 2d 263, 194 P.2d 713 (1948).

35 E.g., Moore v. Hoffman, 125 Cal. 90, 57 Pac. 769 (1899).

30 See, e.g., Moore v. Hoffman, 125 Cal. 90, 57 Pac. 769 (1899),

37 Krieg v. Crawford, 59 Cal. App. 309, 210 Pac. 636 (1922). 
they thereafter have in the land covered by the homestead are in the nature of those of remaindermen or reversioners." Since the "remainder" serves no homestead purpose, it gives the children who have attained majority an unfair advantage over the decedent's creditors and devisees. In order to eliminate this advantage the minor children should be given the same interest in a homestead from community property as they have in a lomestead from separate property. ${ }^{\mathbf{3 0}}$

If there are no minor children, the widow may terminate the probate homestead by a conveyance thereof. ${ }^{40}$ The right to convey the property exists as soon as the order sets apart the homestead. ${ }^{41}$ Since the probate court may direct a sale of the property in the interests of the minors, ${ }^{42}$ it is probable that if the children were the sole owners of the property they could, with court approval, terminate the probate homestead by a conveyance through their guardian.

The duration of a probate homestead selected from the separate property of the decedent may not exceed the hfetime of the widow or the minority of the child. ${ }^{43}$ In the discretion of the court, the homestead may be assigued for a more limited period of time; ${ }^{40}$ the most important factor in determining the duration of a limited probate homestead is the needs of the family. Where the needs are sliglit, the appellate courts will uphold assignments of a year or less. ${ }^{45}$ If the widow is young and likely to remarry an assignment during her widowhood will normally give her adequate protection. An assignment for her lifetime will, if sle does remarry, give her more protection than the legislature intended. ${ }^{48}$

A probate homestead selected from property which the decedent and his wife owned as tenants in common must also be limited in duration if the decedent's undivided interest in the property was lis separate property. ${ }^{47}$ In a recent case on this point, the court, in answer to the widow's contention that the limited assignment divested her of her

38 Moore v. Hoffman, 125 Cal. 90, 93, 57 Pac. 769, 770 (1899).

${ }^{30}$ See text accompanying note 43 infra.

40 Cf. Otto v. Long, 144 Cal. 144, 77 Pac. 885 (1904); Estate of Hamilton, 120 Cal. 421, 52 Pac. 708 (1898).

11 See McHarry v. Stewart, 35 Pac. 141 (1893).

42 See, e.g., Estate of Hamilton, 120 Cal. 421, 52 Pac. 708 (1898).

43 Cax. Prob. Code $\$ 661$.

44 See, e.g., Estate of Bonner, 222 Cal. App. 2d 426, 35 Cal. Rptr. 264 (1963).

45 E.g., Estate of Bonner, 222 A.C.A. 476, 35 Cal. Rptr. 264 (1963) (1 year); Estate of Somers, 84 Cal. App. 2d 726, 191 P.2d 776 (1948) (6 months); Estate of Ettlinger, 56 Cal. App. 2d 603, 132 P.2d 895 (1943) (5 months).

46 If her second husband predeceased her she could claim a second probate homestead from his estate. Higgins v. Higgins, 46 Cal. 259 (1873).

47 See Estate of Adams, 228 A.C.A. 299, 39 Cal. Rptr, 522 (1964); Estate of Maxwell, 7 Cal. App. 2d 641, 46 P.2d 777 (1935). 
fee title to her undivided one-half interest, pointed out that the probate homestead was solely concerned with the decedent's interest. ${ }^{48}$ If this holding means that only an undivided one-half of the property is impressed with homestead characteristics, then it may give too little protection to the widow, since her undivided interest might still be sold in order to satisfy the claims of subsequent creditors. It is unclear whether the buyer would be able to go into possession before the expiration of the homestead. An analogous situation arose in Moore v. Hoff$m a n,{ }^{49}$ where the children, after attaining majority, conveyed a portion of their interest in the probate homestead to a third person. The court refused to allow the grantee to invade the widow's right to sole occupancy, thereby postponing the grantee's right to enjoyment of his interest until after the expiration of the homestead. The same result would be appropriate in the above situation in order to give the widow the maximum amount of protection.

\section{IV}

PERSONS ENTITLED TO THE PROBATE HOMESTEAD

Although the statute ${ }^{50}$ seems clear in its mandate that the probate homestead must be set apart for the use of the surviving spouse and minor children, the question of who is to benefit by its provisions and who is excluded from enjoyment of the rights it confers has been the subject of extensive litigation.

Since the policy of the legislation places the welfare of the decedent's surviving family above the interests which others have in an estate, the court has made the right a personal one which abates on the death of the widow or the attaining of majority by a child ${ }^{51}$ and which cannot be asserted by others holding by assignment or succession. ${ }^{52}$

\section{A. Rights of the Widow}

When there are no children, the widow is entitled to have the property set apart for her own use. ${ }^{53}$ If there are minor children, the family is treated as a unit so that the court cannot set aside a probate homestead for the widow alone or the children alone. ${ }^{54}$ In Estate of Branam, ${ }^{55}$ the widow attempted to waive her right to a probate homestead by stipu-

48 Estate of Adams, 228 A.C.A. 299, 39 Cal. Rptr. 522 (1964).

49125 Cal. 90, 57 Pac. 769 (1899).

50 Cal. Prob. Code $\$ 661$.

51 See, e.g., Estate of Still, 117 Cal. 509, 49 Pac. 463 (1897).

62 E.g., Estate of Blair, 42 Cal. 2d 728, 269 P.2d 612 (1954).

53 E.g., Estate of Hessler, 2 Coffey's Pro. Dec. 354 (1895).

54 Estate of Branam, 66 Cal. App. 2d 309, 152 P.2d 354 (1944).

55 Ibid. 
lation. When she later changed her mind and petitioned the court for a probate homestead for herself and the two minor children of her marriage with the decedent, the court set the property apart for the minor children only. The appellate court reversed on the grounds that it is contrary to the pohicy of the law that the children be provided a home from which they would have the right to exclude their parent. Since the widow could not forfeit the probate homestead rights of the minors, her attempted waiver of her own right was held ineffective. Although there are as yet no other cases on this point, the holding could, as will appear below, have significant import on the cases involving the rights of separated and divorced spouses.

Since the surviving spouse's right to a probate homestead is based upon the status of widowhood-the court being powerless unless such is estabhshed ${ }^{56}$-the marital status of the "widow" and the decedent is of primary importance. When a widow remarries she ceases to be the widow of her first husband and is no longer entitled to a probate homestead from his estate. ${ }^{57} \mathrm{~A}$ husband may effectively deprive his wife of a probate homestead by securing a divorce. The divorce terminates the marital status ${ }^{58}$ and when the husband thereafter dies, his ex-wife is not his widow.

Difficult problems of status arise when the spouses are separated or have obtaimed an interlocutory, but not a final, divorce decree. ${ }^{50}$ In this area cases involving the right to a family allowance ${ }^{00}$ are cited authoritatively in cases deahing with the right to a probate homestead. ${ }^{61}$

An analysis of the cases prior to 1946 shows that whenever the court denied the widow a probate homestead in the estate of her estranged husband it was either because she expressly waived her right to the probate homestead ${ }^{62}$ or because she was at fault in causing the disruption of the marriage. ${ }^{03}$ Whenever the court awarded a probate homestead the

${ }^{56}$ E.g., Estate of Goodale, 5 Coffey's Pro. Dec. 288 (1891).

57 Ibid.

58 E.g., Williams v. North Carolina, 317 O.S. 287 (1942).

59 The interlocutory decree of divorce does not dissolve the marriage. In Estate of Nelson, 224 A.C.A. 138, 36 Cal. Rptr. 352 (1964), the court held that it is no defense to a widow's petition that she at one time filed for divorce if she and decedent were living together as husband and wife at the time of his death.

C0 For a definition of the family allowance, see Probate Code $\S 680$.

61 See, e.g., Estate of Brooks, 28 Cal. 2d 748, 171 P.2d 724 (1946).

62 See Estate of Boeson, 201 Cal. 36, 255 Pac. 800 (1927); Estate of Sloan, 179 Cal. 393, 177 Pac. 150 (1918); Estate of Yoell, 164 Cal. 540, 129 Pac. 999 (1913); Wicksham v. Comerford, 96 Cal. 433, 31 Pac. 358 (1892).

63 See Estate of Bose, 158 Cal. 428, 111 Pac. 258 (1910); Estate of Miller, $158 \mathrm{Cal}$. 420, 111 Pac. 255 (1910); Estate of Noah, 73 Cal. 583, 151 Pac. 287 (1887); Estate of Egeline, 53 Cal. App. 2d 368, 127 P.2d 948 (1942); Estate of Ruiz, 53 Cal. App. 2d 363, 
marital difficulties were the fault of the decedent. ${ }^{64}$ Although this distinction based on fault is the subject of much vague dictum it is never clearly articulated in the holdings. Hence, when the question was raised m 1946 in Estate of Brooks $s^{65}$ as to whether a widow who had obtained an interlocutory decree was entitled to a family allowance and a probate homestead the court felt constrained to choose between what it called two different lines of authority. The opinion refers to the fault concept, but when it surveys the cases it concludes that one he of authority denied the widow any rights in her husband's estate if she was not entitled to support at the time of his death and the other hine denied her these rights only if she had expressly waived them. In the face of this seeming contradiction the court said, "Our choice must be governed primarily by a consideration of what the legislature intended when it enacted the provisions for the 'support of the family' involved in all those cases .... The cases that do not insist upon the condition that the wife be entitled to support seem to lose sight of the purposes for which an allowance is granted." ${ }^{\prime 66}$ Since the widow had been awarded an interlocutory decree which made no provision for her support, she was denied a family allowance. This determination was held decisive as to her right to a probate homestead.

The greatest virtue of the right-to-support test is its simplicity. If a widow has been legally entitled to receive support from her husband she is entitled to a probate homestead from his estate even if they have been living separately or if one spouse has obtained an interlocutory decree. However, in order for the wife to establish her right to support in a divorce action commenced by her, she inust get personal jurisdiction over her husband. ${ }^{67}$ Where slie is unable to do so, the court could augment its sole criterion of right to support with its earlier concept of waiver. The wife could be held not to have waived her right to a probate homestead if slie has made a bona fide effort to fulfill the requirements for an in personam action. ${ }^{68}$

127 P.2d 945 (1942); Estate of Fulton, 15 Cal. App. 2d 202, 59 P.2d 508 (1936); Estate of Cameto, Myrick's Pro. Dec. 42 (1873); Estate of Byrne, Myrick's Pro. Dec. 1 (1872).

64 See Estate of Bidigare, 215 Cal. 28, 8 P.2d 122 (1932); Estate of Henningsen, 199 Cal. 103, 247 Pac. 1082 (1926); Estate of Parkinson, 193 Cal. 354, 224 Pac. 453 (1924); Estate of Gould, 181 Cal. 11, 183 Pac. 146 (1919); Eproson v. Wheat, 53 Cal. 715 (1879); Estate of Malouf, 67 Cal. App. 2d 589, 155 P.2d 121 (1945); Estate of Hale, 117 Cal. App. 545, 4 P.2d 263 (1931); Estate of Ehler, 115 Cal. App. 403, 1 P.2d 546 (1931); Estate of Breitter, 69 Cal. App. 424, 231 Pac. 351 (1924).

6528 Cal. 2d 748, 171 P.2d 724 (1946).

66 Estate of Brooks, supra note 65 , at 755, 171 P.2d at 727.

67 E.g., Baker v. Baker, 136 Cal. 302, 68 Pac. 971 (1902); De La Montanya v. De La Montanya, 112 Cal. 101, 44 Pac. 345 (1896).

68 For service of process requirements for an in personam judgment, see Code of Civil Procedure $\$ \$ 412,413,417$. 
A problem about which no cases have arisen involves the effect of the presence of minor children on the widow's right to a probate homestead when the spouses are separated, or when one has obtained an interlocutory divorce decree. If the decree makes no provision for alimony, then the court must face a dilemma of its own making. The widow is not entitled to a probate homestead, ${ }^{69}$ but she cannot by her actions deprive her minor children of their own right to have the property set aside. ${ }^{70}$ However, as indicated earher, neither can the court set apart to the children a home from which they would have the right to exclude their parent. $^{71}$ In keeping with the overriding policy of homestead legislation-to provide a shelter for the surviving family-a wise course would be to assign a homestead to the minor children and appoint the widow as guardian of the property with a right of occupancy until the youngest child has attained majority. If the homestead were assigned out of the separate property of the decedent the same arrangement could be made, with the property going to the children only until they reached majority rather than in fee. In either case the children would not be deprived of their probate homestead rights, the mother could not be excluded from the children's home, and the widow who was not entitled to support would get no property interest from the decedent's estate.

A third ramification of the adoption of the right to support test as a basis for the awarding of a probate homestead is its effect on the rights of the putative spouse. Upon the dissolution of a putative marriage, the wife is not entitled to alimony; her recovery is limited to the reasonable value of services rendered to the other spouse less the value of support and maintenance which he furnished her. ${ }^{72}$ Since alimony is a continuation of the support to which a wife was entitled during the marriage, refusal to award alimony to the putative spouse must mean that she was not legally entitled to support. Therefore, upon the dissolution of the putative marriage by death, if the right to support test is applied, the putative spouse would not be entitled to a probate homestead. A putative widow's petition for a family allowance which was contested by the decedent's legal wife was denied on the basis of the above reasoning. ${ }^{73}$ Although there have been no cases involving the right to a probate homestead, the position of the court that cases involving the two rights are authoritative each for the other ${ }^{74}$ supports the conclusion of a probable denial of the riglit.

69 E.g., Estate of Brooks, 28 Cal. 2d 748, 171 P.2d 724 (1946).

70 Estate of Blair, 42 Cal. 2d 728, 269 P.2d 612 (1954).

71 Ibid.

72 Sanguinetti v. Sanguinetti, 9 Cal. 2d 95, 69 P.2d 845 (1937).

73 Estate of Cooper, 97 Cal. App. 2d 186, 217 P.2d 499 (1950).

74 E.g., Estate of Brooks, 28 Cal. 2d 748, 171 P.2d 724 (1946). 
Since the children of a void marriage are legitimate, ${ }^{75}$ those who are minors would be entitled to a probate homestead and the court would be faced with the same problem as in the separation cases. However, the solution proposed above, while equally workable here, is less fair. Although the putative spouse is not entitled to support, she does have many rights of a legal spouse. ${ }^{76} \mathrm{~A}$ case involving the rights of the minor children of a putative marriage to a probate homestead would serve as an excellent vehicle for extending the probate homestead right to the putative widow as well.

\section{B. Rights of the Minor Children}

Most of the questions which deal with the rights of minor children to a probate homestead in the estate of their deceased parent are straightforward and can be answered by a reading of the statute. The words "minor children" refer to the children of the decedent and not to his grandchildren. ${ }^{77}$ As with the rights of the widow, the minor's rights are superior to the claims of creditors of the estate ${ }^{78}$ and as indicated above, the conduct of the widow cannot alter those rights.

If a parent survives, the minor children are entitled to one-half of the probate homestead in equal shares; if there is no surviving parent then the whole belongs to the minor child or children. ${ }^{78}$

The most difficult question which the court has faced in this area concerned the rights of a minor child of the decedent by a former marriage, when the decedent was survived by his second wife. In Estate of Rosen$a u r^{80}$ the court treated the problem as one of statutory interpretation and concluded that "When a spouse survives a homestead cannot be set apart for a minor child alone but it must be for such spouse and the minor child or children. Hence since decedent left a spouse who still survives, the minor son of the former marriage is not entitled to have a homestead set apart for his use." ${ }^{81}$ The court rejected the minor son's contention that since decedent had the duty to support him under the property settlenent agreement his right to support was determinative of his right to a probate homestead. In so doing, the court limited the holding in Estate of Brooks ${ }^{82}$ to situations involving the rights of the surviving widow.

75 CAT. Civ. CODE § 85.

${ }^{76}$ For a discussion of the rights of a putative spouse in California see Comment, 50 CAxTr. L. Rev. 866 (1962).

77 Estate of Spinetti, 3 Coffey's Pro. Dec. 306 (1894).

78 See, e.g., Estate of Still, 117 Cal. 509, 49 Pac. 463 (1897).

79 CAL. Prob. CODE $\$ 667$.

80107 Cal. App. 2d 461, 237 P.2d 17 (1951).

81 Estate of Rosenaur, supra note 80, at 462, 237 P.2d at 18.

8228 Cal. 2d 748, 171 P.2d 724 (1946). 
The result in this case is unfortunate since it makes the rights of the minor children of divorced parents wholly dependent upon the fortuitous circumstance of the remarriage of one or the other parent. It would not be doing violence to the language of the statute to read the words "surviving spouse and the minor children" to include the children of the decedent of a former inarriage. ${ }^{83}$ If the family home of the decedent and his widow is the only suitable homestead property in the estate, then priority should be given to the widow. However, if the estate has sufficient assets, the court should order the personal representative to purchase a home for the minor children. Since the property in this situation would not be the community property of the decedent and his ex-wife-the mother of the minor children-it could only be assigued for a period not to exceed the minority of the children. ${ }^{84}$ Therefore the rights of others in the estate would only be postponed. Furthermore, if the court is given discretion to deny a probate homestead when it appears that the primary purpose of the petition is to keep the property from another, ${ }^{85}$ the likelihood of a suit by the decedent's ex-wife on behalf of her children solely for its nuisance value will be significantly reduced.

\section{Rights of the Heirs and Devisees of the Decedent}

Since the property set apart as a probate homestead out of the community property of the decedent and the surviving spouse must be set apart in fee, ${ }^{86}$ there is a definite limitation upon the testamentary power of the decedent. Any attempt to devise his share of the property ${ }^{87}$ which is later assigued as a probate honiestead is inoperative. Therefore with respect to community property the expectancies of the heirs and devisees of the decedent are subordinate to the policy of the probate homestead.

When the property set apart is the separate property of the decedent, it may only be set apart for a limited period, and subject to the home-

83 In Estate of Goulart, 218 Cal. App. 2d 260, 32 Cal. Rptr. 229 (1963), the minor children of a previous marriage of decedent petitioned for a family allowance from the estate of their father. Their petition was opposed by the decedent's surviving widow on the basis of the decision in Estate of Rosenaur, 107 Cal. App. 2d 461, 237 P.2d 17 (1951). The court, again basing its reasoning on statutory interpretation, beld that the family allowance, unlike the probate homestead, is not required by statute to be awarded to the surviving widow and minor children jointly. Hence the children were awarded a separate family allowance. This is the ouly deviation from the court's position that the rights to a probate homestead and a family allowance are based on the same criteria. See also Estate of Jameson, 224 Cal. App. 2d 517, 36 Cal. Rptr. 802 (1964).

84 See text accompanying note 25 supra.

85 See text accompanying notes 15-16 supra.

86 See, e.g., Estate of Rogoff, 205 Cal. App. 2d 650, 23 Cal. Rptr. 334 (1962); Estate of Davis, 86 Cal. App. 2d 263, 194 P.2d 713 (1948).

87 Probate Code $\S 201$ provides that one-half of the commumity property is subject to the testamentary power of the decedent. 
stead right the property remains subject to administration.$^{88}$ For historical reasons, the precise meaning of this provision is open to question. In Estate of Walkerly, ${ }^{89}$ a case decided under a predecessor statute ${ }^{90}$ which provided that the title to the property vested in the heirs subject to the homestead order, the court held the word "heirs" could not be construed to mean "heirs or devisees." The effect of this holding, which the court agreed seemed unusual, ${ }^{92}$ was to completely remove the property later designated as a probate homestead from the testamentary power of the decedent.

The language of the statute ${ }^{93}$ was amended in 1907 into the same form in which it was later incorporated into Probate Code section 661-keeping the assigued property subject to administration. ${ }^{94}$ Although the Code Commissioner said ${ }^{95}$ that the amendment would avoid the rule affinned in Estate of Walkerly" this result is not inevitable. The phrase "subject to administration" does not necessarily include the phrase "subject to testation." If the legislature had intended to restore to the testator the power of testamentary disposition of the remainder, it should have made its intent unmistakably clear. ${ }^{97}$

The question of which reading to accord to the new language has importance not only for the potential heirs or devisees of the husband, but also for those who may later have an interest in the estate of the widow. The rule in Estate of Walkerly ${ }^{98}$ effectively prevented the testator from completely disinheriting his wife, since she would, after the expiration of the himited period of assigunient, take an intestate share of the property set aside as a probate homestead. ${ }^{99}$

The court is, however, fully able to protect the widow whose deceased husband's estate is comprised only of his separate property by assigning to her a probate honestead for hife im a suitable piece of that property, even if the decedent has devised that parcel to another. There is no

88 Cat. Prob. Code $\$ 661$.

89108 Cal. 627, 41 Pac. 772 (1895).

90 Formerly Code of Civil Procedure § 1468, enacted 1872.

91 Estate of Walkerly, 108 Cal. 627, 41 Pac. 772 (1895).

92 Id. at 655,41 Pac. at 778.

93 Formerly Code of Civil Procedure § 1468, enacted 1872.

84 Cal. Stats. 1907, ch. 507, at 939.

95 Quoted in DeErING, Code of CivIr Procedure 799 (1929).

98108 Cal. 627, 41 Pac. 772 (1895).

97 It could have done so by adopting the language of Civil Code $\$ 1265$. This section, which deals with the devolution of a marital homestead selected from the decedent's separate property without his consent, has provided since 1873 that the property shall go to the heirs or devisees, subject to the power of the court to assigu it for a limited period to the family of the decedent.

98108 Cal. 627, 41 Pac. 772 (1895).

99 Cad. Prob. CODE $\$ \S 221,223-24$. 
policy which favors giving the remainder following the widow's estate to her devisees rather than to the devisees of the predeceased husband..$^{100}$ So long as the widow has been made secure during her lifetime, the predeceased husband's wishes as to the ultimate disposition of his separate property slould be given effect, smce "... it is unquestionably the general policy of our law to allow full power of testamentary disposition-saving as that power may be abridged by specific enactments." ${ }^{101}$ Therefore, althougl the term "subject to administration" is not wholly free from ambiguity, the court should resolve the question in favor of restoring to the decedent the power of testation over the separate property assigned by the court as a probate homestead.

\section{V}

\section{CREDITORS RIGHTS AGAINST THE PROBATE HOMESTEAD}

The basis of existing problems in the area of creditors' rights against the probate homestead is a complete lack of a statutory definition of these riglits. The probate homestead is not treated under Civil Code section 1241 which enumerates the conditions under which a marital homestead is subject to execution and forced sale, nor is it subject to the provisions of Civil Code sections 1245-59 which outline the procedure which creditors must follow in order to reach any excess over the exemption limit. Since no analogous statutes deal with the probate homestead, creditors must look to case law to determine their rights.

\section{A. Creditors of the Estate}

While the rights of the general creditors of the estate should be considered by the court when setting aside the lomestead, ${ }^{102}$ it may nevertheless be set apart irrespective of the claims of creditors even when it constitutes the whole estate. ${ }^{103}$

The order which sets apart the probate homestead does not impair or

100 Probate Code $\S 229$, which provides for the distribution of former separate property of a previously deceased spouse where the decedent leaves no surviving spouse or issue, can be used as a basis for reasoning that the policy in California favors the opposite result. If the widow died intestate, the statute would govern since the remainder interest would have come to the widow by descent. However, in the event the widow died testate, the statute would not apply and the question of whether the husband's devisee or the wife's devisee should take would be squarely presented.

101 Estate of Walkerly, 108 Cal. 627, 653, 41 Pac. 772, 778 (1895).

102 Estate of Nelson, 224 Cal. App. 2d 138, 36 Cal. Rptr. 352 (1964).

103 Estate of Wells, 3 Coffey's Pro. Dec. 229 (1905).

In Estate of Tittel, $139 \mathrm{Cal} .149,72$ Pac. 909 (1903), the court held that if the property is the separate property of the decedent, the remainder, which by the terms of the statute, is subject to administration, can be sold in order to satisfy the claims of the general creditors of the estate. 
destroy any mortgage or other lien on the property. ${ }^{104}$ The property is assigned subject to any liens existing thereon. The court has no power to order the personal representative to discharge an encumbrance on the probate homestead. ${ }^{105}$ The widow is not protected by Probate Code section 750 which exempts specific devises from payment of the debts of an estate, since her title comes from the homestead order and not by devise. ${ }^{108}$ Neither can she take advantage of Probate Code section 735 which provides that any claims secured by liens or encumbrances on the homestead must be paid out of the funds of the estate, since the section has been construed to cover only marital lomesteads. In establishing this rule the supreme court said, "We have looked in vain to find any law authorizing the court to discharge liens upon such a homestead. Where a homestead has been selected and recorded prior to the death of one of the spouses ... [the predecessor section of Probate Code section 735] makes provision for the extinguishment of liens and encumbrances upon it, but [the section] has to do exclusively with homesteads declared during the hifetime of the spouses. The law has not seen fit to make the same provision as to probate homesteads."107

A special situation exists with respect to the vendor's lien. In Estate of Ried, ${ }^{108}$ the creditors had a vendor's lien as the result of a contract of sale with the decedent. The decedent was the equitable owner, subject only to divestment for breach of the contract. On the death of the purchaser, the obligation to pay the purchase price devolved upon the personal representative as a contract debt and the creditors had only a personal privilege to enforce the ken in an action on the contract; the lien was not an absolute charge on the land. Since the creditors had filed their claim on the estate, they had, the court held, waived their vendor's lien. Had they not done so, the court added, they could have brought suit to subject the homestead to the hen for the payment of the unpaid purchase price.

Where the administrator mortgaged the property before the probate homestead was set apart, the court held that the debt should be paid out of the general assets of the estate, or if these were not sufficient, non-homestead land covered by the same mortgage must be sold first and the proceeds applied agamst the encumbrance. ${ }^{109}$ If the mortgage were not completely paid by the above process, the liomestead would be assigned subject to the lien for the unpaid amount.

104 Estate of McCauley, 50 Cal. 544 (1875).

105 Estate of Huelsman, 127 Cal. 275, 59 Pac. 776 (1899).

100 Ibid.

107 Id. at 277,59 Pac. at 776.

10826 Cal. App. 2d 362, 79 P.2d 451 (1938).

109 Estate of Shively, 145 Cal. 400, 78 Pac. 869 (1904). 


\section{B. Creditors of the Homestead Owner}

Although the widow may mortgage her interest in the probate homestead, the mortgagee takes subject to the homestead rights of the minor children while they endure. Therefore, if the mortgage is foreclosed, the purchaser at the foreclosure sale would not have a right of entry as cotenant with the children until the termination of the homestead when the youngest child attained majority. ${ }^{110}$ Reciprocally, if the children were to encumber their interest in the homestead after they have attained majority the widow's right of sole occupancy would be protected in the event of a forced sale. ${ }^{111}$

When the owner of a probate homestead contracts for improvements on the property and then fails to pay the contractor or materialman for such improvements, a mechamic's lien on the property may be foreclosed for the benefit of the lienholder. If the homestead is for a limited period only, the purchaser may enjoy the title until the homestead expires; the interest of the remainderman is not extinguished by the foreclosure of a mechamic's bien. ${ }^{112}$

Section 674 of the Code of Civil Procedure provides that, upon recordation of an abstract of a judgment, the judgment becomes a hen on all property of the judgment debtor not exempt from execution which is owned by him at the time. The cases uniformly confirm that a judgment lien cannot attach to a valid marital homestead. ${ }^{113}$ Although there have been no cases which involve the specific question of whether a judgment hen can attach to a probate homestead, it is clear from the language of section 674 that it cannot. Therefore, the probate homestead property may

110 E.g., Hodge v. Norton, 133 Cal. 99, 65 Pac. 123 (1901); Hoppe v. Hoppe, 104 Cal. 94, 37 Pac. 894 (1894).

111 E.g., Moore v. Hoffman, 125 Cal. 90, 57 Pac. 769 (1899).

112 See MacQuiddy v. Rice, 47 Cal. App. 2d 755, 118 P.2d 853 (1941). The court indicated in this case that both the mechamc's lien and the probate homestead are favored in the law. However, since the owner of the homestead had contracted for the work the court felt that in all good conscience the hien should be foreclosed for the benefit of the lienholder. Therefore it does not necessarily follow from this case that had the homestead owner paid the general contractor who then failed to pay the lienholder the court would have reached the same result. Nor may the court reach this result if there are minor children involved, since the widow cannot forfeit their probate homestead rights. Cf. Estate of Branam, 66 Cal. App. 2d 309, 152 P.2d 354 (1944). Although the entire property is benefited the lien may only attach or be foreelosed against the interest of the widow. Cf. Hodge v. Norton, 133 Cal. 99, 65 Pac. 123 (1901); Hoppe v. Hoppe, 104 Cal. 94, 37 Pac. 894 (1894). In the instant case only the interest of the life tenant was foreclosed, although presumably the remainder interest also benefited from the improvements.

113 E.g., Boggs v. Dunn, 160 Cal. 283, 116 Pac. 743 (1911); Bowman v. Norton, 16 Cal. 213 (1860); Ackley v. Chamberlain, 16 Cal. 181 (1860); Claussenius v. Anderson, 216 Cal. App. 2d 171, 30 Cal. Rptr. 772 (1963); Coca Cola Bottling Co. v. Fehiciano, 45 Cal. App. 2d 680, 114 P.2d 604 (1941). 
not be sold in order to satisfy a judgment rendered against the hoinestead owner after the property is assigned.114

An unsecured creditor of the homestead owner has no recourse to the probate homestead for satisfaction of his claim since he is neither protected by statute nor named in the cases as one who may execute against the property. He cannot better his position by reducing his claim to judgment.

Even if the owner of the probate homestead is adjudicated a bankrupt, the unsecured creditor's claim cannot reach the homestead property. Section 6 of the Bankruptcy Act ${ }^{115}$ provides that the provisions of the act shall not affect the allowance to bankrupts of the exemptions which are prescribed by the law of the state of their donncile. Therefore where the state allows a homestead exemption to the debtor, the same exemption may be set apart to him in the bankruptcy proceeding. ${ }^{116}$ Although all of the cases in which California law has been controlling have involved the marital homestead, a probate homestead should receive the same treatment simce it is also an exemption under state law. ${ }^{117}$

\section{VI \\ WHY A PROBATE HOMESTEAD?}

The probate homestead serves two important purposes: It provides a home for the surviving family of a decedent regardless of the claims of creditors of the estate and devisees and it secures this home to the family against the demands of subsequent creditors. There are different considerations involved in evaluating each of these functions of the probate homestead in order to determine whether legislation which establishes such a property interest is desirable.

When the testator has carefully planned his estate and it is solvent,

114 Code of Civil Procedure $\$ 674$ further provides that the lien of a recorded judgment attaches to after acquired property. Here the analogy to cases involving the marital lomestead ceases. Since property cannot be acquired with marital lomestead characteristics already impressed upon it, the anticipatory judgment lien would always be prior to the lomestead declaration. On the other land, the probate lomestead is exempt from execution the moment it is assigned to the widow; the court leld in Otto v. Long, 144 Cal. 144, 77 Pac. 885 (1904), that the order setting it apart need not be recorded in order to be effective against creditors. This means that if an anticipatory judgment lien las been filed against the person who later becomes the homestead owner, the after acquired probate lomestead, which is never "property not exempt from execution" is beyond the reach of the judgment creditor.

11511 U.S.C. \& 24.

116 In re Wilson, 123 Fed. 20 (9th Cir. 1903); In re Kossack, 113 F. Supp. 884 (S.D. Cal. 1953).

117 A lien for federal income tax may be foreclosed against the probate lomestead, since the "collector is not required to recognize or respect state notions of lomestead exemptions in his search for property." Jones v. Kemp, 144 F.2d 478, 480 (10th Cir. 1944). 
a probate homestead for the purpose of providing a home for the surviving family should not be necessary. ${ }^{118}$ However, if these two conditions are not met, the family inay have its security threatened or be left hoineless.

The right to a probate homestead is the only property interest which a widow can assert in an estate which consists solely of the separate property of the decedent. It compensates to a degree for the lack of dower rights or a forced share in the estate; with one exception, neither of these rights are recognized in Cahifornia. ${ }^{119}$ By giving the probate court the power to set aside a probate homestead in the separate property of the decedent for a limited period which may not exceed the lifetime of the widow or the minority of a child, the legislature has achieved a balance among all of those persons who may have an interest in the estate. If the words "subject to administration" are interpreted to include "subject to testation," the widow's rights do not cut off the rights of the husband's devisees, but only postpone them until the expiration of the homestead. ${ }^{120}$ Thus the property is ultimately disposed of according to the wishes of the testator. Creditors of the estate can receive at least partial satisfaction of their clamis since the remainder is an asset of the estate which may be sold for this purpose.

Where the decedent has died intestate leaving only separate property, the reasons for allowing the court to set apart a probate homestead are less compelling but are nevertheless persuasive. Where the decedent is survived by his widow and minor children or by the minor children only, the entire estate descends to them in fee by intestate succession. ${ }^{121}$ Unless the estate is insolvent, the surviving family is thus assured of a home from the estate. However, if the decedent leaves a surviving spouse and no issue, the surviving spouse would, in the absence of provisions for a probate homestead, be entitled to only one-half the estate. The other half would go to the other heirs. ${ }^{122}$ A probate homestead under such circumstances prevents these heirs from interfering with the sole possession and occupation of the home by the widow. As with the rights of devisees, the rights of the heirs at law are postponed rather than ehminated.

If the home is the comununity property of the decedent and the surviving spouse there is a different balancing of interests. Since the decedent has the power of testamentary disposition over one-half of the community

118 Unless the widow specifically renounces her right to a probate homestead in this situation, there may be gift tax consequences. For a discussion of this problem, see Brown, A Tax Hazard: The Right to a Probate Homestead, 36 CaL. S.B.J. 220 (1961).

110 Probate Code $\S 201.5$ gives the surviving spouse a forced share of the quasicommunity property.

120 See text accompanying notes 88-101 supra.

121 CaL. Prob. CODE $\S \S 221,222$.

122 Cat. Prob. Code $\S 223$. 
property, ${ }^{123}$ again the initial purpose of allowing the court to assign a probate homestead is to prevent third persons from disturbing the widow in her possession of the home. The minor children are given rights in the property which they otherwise would not have. ${ }^{124} \mathrm{~A}$ probate homestead in community property cuts off the rights of all other persons who may have an interest in the particular property set apart, since it is assigned in fee. Thus the testamentary power of the decedent to dispose of his share of the home has been effectively limited. This is consistent with one of the theoretical bases of the community property system; it prevents the husband from disinheriting his widow as to property which she helped him to acquire. That general creditors, heirs, and devisees are completely deprived of the homestead property reflects the decision of the legislature that as to community property the rights of the surviving family are to be preferred. As with any attempt to balance the interests of various parties, the result reached by the legislature is one with which reasonable men could differ. The rule does have the advantages of relative simplicity and uniformity of application. Since the property is assigned subject to the hens and encumbrances existing thereon, secured creditors are not prejudiced by the assignment in fee.

If the probate homestead legislation existed only to provide the surviving family with a home from the estate of the decedent and did not also protect this home from the demands of subsequent creditors, it would still serve a necessary function. The latter form of protection is not unique to the probate homestead. It serves the same purpose as the protection afforded by the marital homestead and therefore an evaluation of this purpose must first turn on an appraisal of the entire framework of homestead legislation. Where the parties have declared a marital homestead, after the death of one spouse the property devolves upon the survivor with the marital homestead characteristics intact. ${ }^{125}$ Since these characteristics differ somewhat from those of the probate homesteadalthough they serve the same purpose-a comparative analysis is necessary in order to complete the evaluation of the probate homestead.

Marital homestead legislation has been widespread throughout this country. Although such statutes differ in form, their purpose is the same- to secure to a family a place in which to live free from the demands of creditors. The California legislature has shown its continued support of the marital homestead by raising the exemption himits in order to make

123 Cas. Prob. Code $\S 201$.

124 For a proposal to limit the rights given to the minor children, see text accompanying notes 38-39 supra.

125 Cax. Crv. Code $§ 1265$; CaL. Prob. Code $§ 663$. 
them realistic. ${ }^{126}$ Likewise, the California courts have shown their agreement with the theory of homestead protection by reiterating the necessity for construing marital homestead provisions generously in favor of the owner of the property. ${ }^{127}$

Since the existence of a marital homestead is a matter of public record, persons who extend credit to the owner have at least constructive notice that the property will be exempt from execution in order to satisfy their claims. If they want to protect themselves, they may do so by demanding a hen upon the property as security. When a tort creditor is involved, it is meaningless to talk in terms of prior notice, yet he is nevertheless prevented from satisfying his judgment out of the homestead property. However, where the value of the marital hoinestead exceeds the exemption limit, he can reach the excess by following a statutory procedure, ${ }^{128}$ and a balancing of interests is thereby achieved.

However, with respect to a probate homestead, there is no exemption limit; the property is completely beyond the reach of subsequent unsecured creditors, regardless of its value. This is a major fault of the legislation which governs the probate homestead; it makes possible a result such as that in Estate of Nelson, ${ }^{129}$ where property valued at 244,000 dollars was assigned to the widow. In that case the court pointed out that no other person had an interest in the estate. However, such a result cannot be justified on that basis alone. Since the probate homestead is of a dual nature, the value of the property which is set aside has importance with respect to future events which may bear no relation to the magnitude of its effect on the persons who are interested in the estate.

There is a solution to this problem which would not interfere with the creation of the probate homestead. After the property has been set apart to the surviving family, it could become impressed with the same exemption limit as the marital homestead. ${ }^{130}$ The property could be subject to execution or forced sale under the same circumstances as the marital homestead. Civil Code section 1241, which enumerates the four classes of creditors who may be satisfied out of marital homestead property could be extended to cover the probate homestead as well. This step would be essentially a codification of the rights of creditors of the probate homestead owner as articulated by the California courts. In order to allow all other subsequent creditors to reach the excess value of the probate

126 In 1953 the exemption limit was raised from $\$ 5,000$ to $\$ 12,500$. In 1963 it was raised again to $\$ 15,000$.

127 See, e.g., Strangman v. Duke, 140 Cal. App. 2d 185, 295 P.2d 12 (1956); Parker v. Riddell, 41 Cal. App. 2d 908, 108 P.2d 88 (1941).

128 CAT. Crv. CODE $\$ \S 1245-59$.

120224 Cal. App. 2d 138, 36 Cal. Rptr. 352 (1964).

130 CAL. Crv. CODE $\$ 1260$. 
homestead above the exemption limit, Civil Code sections 1245-59 which establish a procedure for execution against the marital homestead could be extended to apply to the probate homestead as well. If the subsequent creditors can be protected in this manner, a better balance of interests will have been achieved.

\section{VII}

\section{TOWARD MIORE UNIFORM HOMESTEAD IEGISLATION}

Most of the differences which exist between the probate homestead and the marital homestead whicl lias devolved on the surviving spouse liave no rational basis. ${ }^{131}$ Since the two forms of homestead protection serve the same purpose-to provide a secure home for the surviving family of a decedent - and involve the same classes of interested parties, a uniform system of homestead legislation is desirable. The major problem in this area is the difference in the value of the property which is exempt from execution and forced sale in order to satisfy the claims of subsequent creditors. This problem, which was discussed above with respect to justification of the probate homestead, is in the most urgent need of solution. If the exemption limit is not equalized, no amount of uniformity in the other aspects of homestead legislation will make the marital homestead which has devolved on the survivor as desirable as the probate homestead.

The differences which pertain to the persons in whom the homestead vests, the value of the property which may be set apart, and the treatment of hens on the property are not explainable in terms of the nature and purpose of homestead legislation. They seem to be attributable to a combination of two factors: a failure by the legislature to consider both types of homesteads when enacting legislation with respect to

181 At least one significant difference should be retained. When a marital homestead has been declared in the separate property of the decedent with his consent, the property vests in the survivor in fee. CAL. РRob. Code $\$ 663$. On the other hand, where there is no marital homestead or the marital homestead was selected from the separate property of the decedent without his consent, the separate property of the decedent may only be assigned to the survivor for a limited period. CAL. Prob. CoDE $\S 661$. The results in these cases are reasonable when considered in their proper frame of reference. When a person joins in the declaration of a marital homestead on his separate property, he is voluntarily consenting to a transaction which has testamentary significance of which he is presumably aware. Therefore, when the property vests in his widow in fee, it has devolved upon the person whom he intended should receive the property. In the situation where no marital homestead has been declared or the marital homestead was selected from the decedent's separate property without his consent, the decedent may have devised the family home to a third person. In the first instance the interests of the decedent and his widow are the same; in the second the court has to balance the interests of the testator, his widow, and his devisees. It does so by assigning the probate homestead to the widow for a limited period with the remainder kept subject to administration. 
either and an insistence by the courts that when the legislature has treated one type of homestead in a particular way it specifically intended not to do likewise for the other form of homestead.

A marital homestead vests in the survivor at the death of his spouse; ${ }^{132}$ a probate homestead is assigned to the surviving spouse and minor children. ${ }^{133}$ When the minor children are orphaned they are given a probate homestead protection in one of two ways: if the last spouse to survive had a probate homestead, the interests of the minor children in that homestead continues; if the last spouse to survive had no homestead, or had a marital homestead the property can be assigned to the minor children in its entirety as a probate homestead..$^{134}$ The real problem occurs when the interests of the widow and minor children do not coincide. In order to assure that the minor children will continue to have a home after the death of one parent the marital homestead should devolve upon the surviving spouse and minor children in the same manner a probate homestead would be assigned to these persons.

A second difference between the probate homestead and the marital homestead which has devolved upon the survivor is the value of the property which may be set apart. This problem exists apart from the problem of the exemption himits; it has its greatest effect upon the survivor and the creditors of the estate and has less relevance to the question of the rights of subsequent creditors. Although the court has discretion if the property is divisible or if there are two or more suitable properties, there is no himit to the value of property which may be set aside as a probate homestead. ${ }^{135}$ On the other hand, when a marital homestead has been declared on property having greater value than the exemption limit at the time of declaration, on the death of the first spouse, if the property cannot be divided without injury, the court may order it sold and the proceeds divided. ${ }^{136}$ This is a desirable procedure since the proceeds which are distributed to the widow are exempt from execution for a period of six months, ${ }^{137}$ which is ample time for her to purchase a hoine. If the widow desires homestead protection against the demands of subsequent creditors she can execute a declaration of hoinestead on the newly purchased property. Under Civil Code section $1265 \mathrm{a}$, when the newly purchased property is selected as a homestead such selection has the same effect as if the homestead had been created

132 Cax. Civ. Code $\S 1265$; Cax. Prob. Code $\$ 663$.

133 Cax. Prob. Code $\$ 661$.

134 See Estate of Wright, 98 Cal. App. 633, 277 Pac. 372 (1929).

135 Estate of Nelson, 224 Cal. App. 2d 138, 36 Cal. Rptr. 352 (1964).

136 Cax. Prob. Code $\$ \S 664-66$.

137 Cax. Civ. CoDE $§ 1257$. 
at the time the prior declaration of homestead was recorded. Therefore, even if the widow is not a head of family as defined by section 1261 of the Civil Code, she would probably be allowed the benefit of the larger exemption himit afforded such persons ${ }^{138}$ since her husband was alive at the time of the prior declaration of homestead. However, this result could be justified even without the statute. If her husband had declared a marital homestead on property which did not exceed the exemption limit it would devolve upon her with the amount of the exemption unchanged. There is no reason to penalize the widow if the marital homestead declared during the husband's lifetime exceeded the exemption limit. To reduce the exemption limit at the death of the husband would be a windfall to creditors who had extended credit with notice of the homestead, at the expense of the security of the surviving family.

The extension of the statutory procedure to the selection of a probate homestead would give the probate court more flexibility by allowing it some discretion over the value of the property to be set aside. If an exemption himit is imposed as suggested above, the goal of umiformity between the two forms of lomesteads would be furthered.

The final problem which exists because of the failure of the legislature to declare a uniform homestead policy involves the treatment of claims which are secured by a lien on the homestead property. Both the probate homestead and the marital homestead are assigned to the survivor subject to any hens which exist on the property. In the case of the marital homestead, however, Probate Code section 735 provides that encumbrances on the property sliall be paid from the funds of the estate. The California Supreme Court has held that this provision does not apply to encumbrances on the property which is assigned as a probate homestead. ${ }^{139}$ This decision, which created a situation detrimental to the widow and the secured creditor, ${ }^{140}$ is clearly contrary to the purpose of homestead legislation, which primarily considers the interests of these two persons. The only persons who stand to benefit from it are the heirs or devisees of the decedent, whose interests should not, in light of the homestead policy, be served at the expense of the surviving family and creditors of the decedent. This problem would be solved if the provision of Probate Code section 735 were expressly made to apply to the probate homestead property.

138 Civil Code $\S 1260$ provides that the exemption limit for a head of family is $\$ 15,000$. For all other persons it is $\$ 7,500$.

139 Estate of Huelsman, 127 Cal. 275, 59 Pac. 776 (1899).

140 If the secured debt is not yet due the creditor may, in some instances, prefer to keep his hen in order to take advantage of a favorable interest rate. However, this would have to be weighed against the possibility of having to foreclose the hen in order to collect the principal debt. 
The above discussion illustrates that most of the changes which are necessary in order to achieve a uniform system of homestead legislation can be accomplisled by extending the statutes which apply to the marital lomestead so that they govern the probate hoinestead as well. With respect to the marital homestead, the legislature has developed a fair and workable method of balancing the competing claims against the decedent's estate. The developinent of rules which govern the probate homestead has been primcipally left to the court whicl has hesitated to apply legislation governing the marital homestead by analogy to situations involving the probate homestead. Simce the rights of the same persons are involved in both cases and since the two forms of homestead protection serve the same purpose, the legislature and the courts should adopt, wherever feasible, rules applicable to both homesteads equally.

Diana S. Stoppello 